$5-1-2012$

\title{
Nitrous oxide myelopathy posing as spinal cord injury.
}

\author{
George M. Ghobrial, MD \\ Thomas Jefferson University \\ Richard Dalyai, MD \\ Thomas Jefferson University \\ Adam Flanders, MD \\ Thomas Jefferson University \\ James Harrop, MD \\ Rothman Institute, Thomas Jefferson University
}

Follow this and additional works at: https://jdc.jefferson.edu/neurosurgeryfp

Part of the Medicine and Health Sciences Commons

Let us know how access to this document benefits you

\section{Recommended Citation}

Ghobrial, MD, George M.; Dalyai, MD, Richard; Flanders, MD, Adam; and Harrop, MD, James, "Nitrous oxide myelopathy posing as spinal cord injury." (2012). Department of Neurosurgery Faculty Papers. Paper 52.

https://jdc.jefferson.edu/neurosurgeryfp/52

This Article is brought to you for free and open access by the Jefferson Digital Commons. The Jefferson Digital Commons is a service of Thomas Jefferson University's Center for Teaching and Learning (CTL). The Commons is a showcase for Jefferson books and journals, peer-reviewed scholarly publications, unique historical collections from the University archives, and teaching tools. The Jefferson Digital Commons allows researchers and interested readers anywhere in the world to learn about and keep up to date with Jefferson scholarship. This article has been accepted for inclusion in Department of Neurosurgery Faculty Papers by an authorized administrator of the Jefferson Digital Commons. For more information, please contact: JeffersonDigitalCommons@jefferson.edu. 


\title{
Submitted to:
}

\section{Journal of neurosurgery. Spine.}

\author{
And later published as:
}

\section{Nitrous Oxide Myelopathy posing as Spinal Cord Injury}

\author{
Volume 16, Issue 5, May 2012, pages: 489-491
}

\author{
DOI: 10.3171/2012.2.SPINE11532 \\ George M. Ghobrial, Richard Dalyai, Adam Flanders, James Harrop \\ Thomas Jefferson University Hospital \\ Departments of Neurosurgery and Neuroradiology
}

\begin{abstract}
INTRODUCTION: A patient presented with acute tetraparesis and a proposed acute traumatic spinal cord injury which was the result of nitrous oxide myelopathy.

PRESENTATION A 19 year old male sustained a traumatic fall off a 6 foot wall. His examination was consistent with a central cord syndrome with the addition of dorsal column impairment. Cervical MRI illustrated isolated dorsal column signal was suggestive of a non-traumatic etiology.

COURSE His symptoms resolved entirely over the course of 48 hours.

CONCLUSIONS Nitrous oxide abuse is increasing in prevalence. Its toxic side effects can mask B12 and folate deficiency and central cord syndrome. History and radiographic presentation are key to establishing a diagnosis.

Introduction

Central cord syndrome is a common presentations after cervical hyperextension injuries. Nitrous oxide(NO) is utilized as an anesthetic agent, however it is also available as a propellant in pressurized containers such as whipped cream. It is frequently abused for its euphoric and anesthetic effect. ${ }^{8,24}$ The effects of nitrous oxide on the spinal cord have been reported in the literature, ${ }^{4,6,7,15,16,18,19,25,31}$ however, the unique and insidious presentation after cervical trauma has not been documented. Since the abuse of nitrous oxide is increasing in prevalence, this may be an important mechanism for spinal cord injuries and should be considered in the differential in the acute care setting.
\end{abstract}

\section{Case Report}

A 19 year-old male presented with complaints of progressive numbness and weakness in all extremities after a fall over a six foot fence onto his back, one day prior. He denied back pain, bowel or bladder incontinence. Additionally, he denied any relevant past medical or surgical history. Over the course of 
twenty-four hours, his symptoms progressed to an inability to ambulate and numbness in the distal extremities. The patient stated he occasionally abused oxycodone, alcohol, and "huffed" nitrous oxide canisters several times per week. Moreover, he stated he would "huff" as much as twenty pound canisters of nitrous oxide at one setting.

On initial assessment, the patient had minimal neck pain, was hemodynamically stable, and had a Glascow Coma Scale of 15. He was alert and oriented, without apparent cognitive or language deficits. On motor exam however, proximal weakness of $3 / 5$ in the deltoids bilaterally and distally of $2 / 5$ was found. In the lower extremities, the iliopsoas muscle groups were weak (4-/5) and distal groups were $3 / 5$. Hyperreflexia was noted in the bilateral lower extremities. Sensation to light touch and pin prick was absent in the distal extremities as well as vibration and propioception. The sensation loss was not dermatomal. The remainder of the neurological exam was insignificant.

Investigations

Due to the history of NO abuse a vitamin B-12 and folate level were sent and returned within the normal reference ranges. A MRI scan of the cervical spine did not demonstrated any acute traumatic signs such as bony fracture, ligamentous injury, or subluxation. However, the spinal cord parenchymae had significant T-2 signal abnormalities in the posterior columns from C2-7. (Fig. 1-2)

\section{Clinical Course}

Intravenous methylprednisolone was started at an outside institution according to the NASCIS II criteria and since the patient was making progressive improvements was maintained. Thirty-six hours after injury, the patient noted complete resolution of his symptoms. The following day, the patient was discharged home.

Discussion

The National Institute of drug abuse has reported a significant increase in the number of nitrous oxide abuse cases- from 1.5 to 18 million across the span of 2000 to $2001 .^{31}$ Similarly there has been a decrease use as this drug as an anesthetic agent ${ }^{11,21}$ The biochemical effects of NO as an anesthetic

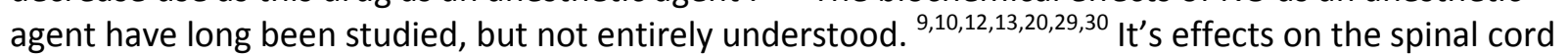
have been recognized since 1959 by Randt, in laboratory studies in cats. ${ }^{26}$

NO abuse tends to present clinically with a predominant effect on the dorsal columns. Vitamin B12 deficiency and folate deficiency can exacerbate this effect. ${ }^{28}$ This effect is hypothesized to occur due to the oxidizing effect of NO on the cobalt group of cobalamin. ${ }^{31}$ In the presence of NO, the covalence of cobalt will change from monovalent to bivalent, which then reacts to irreversibly inactivate vitamin B12. The formation of tetrahydrafolate (THF) is halted by the further inhibition of methionine synthase, which requires B12. THF is vital in DNA synthesis, cell division, and ultimately myelination in the spinal cord. This biochemical pathway is hypothesized to be most vital in the posterior columns. ${ }^{14}$

Regarding evaluation, there are no specific tests to document nitrous oxide exposure. A detailed history is the basis of diagnosis of NO myelopathy. ${ }^{10}$ Vitamin B12 deficiency has been shown to affect vision, hearing, sensory, and motor pathways on evoked studies. ${ }^{10}$ Excluding Vitamin B12 and folate deficiency is important as potential causes of this dorsal column pathology, but do not exclude NO abuse.

The resolution of clinical symptoms in this patient was dramatic and thus atypical for $\mathrm{SCl}$ patients. Likewise, a central cord SCl pattern of injury is atypical in NO myelopathy. One explanation is that a central cord injury did occur in the setting of nitrous oxide intoxication, resulting in a superimposed posterior column myelopathy. Regarding the imaging, the strong hyperintensity of the posterior columns on T2-weighted MR could have obscured the otherwise faint central cord signal that might have been noticed in the absence of posterior column signal change. NO may also manifest as weakness 
due to deficits in proprioception and sensation. This finding in previous literature could explain the rapid recovery that would not typically be observed in central cord myelopathy. ${ }^{6,8,15,16,18}$

Nitric oxide, a rapid and interchangeable form of nitrous oxide in the body, is implicated in the pathophysiology of secondary injury in spinal cord trauma. Liu and associates demonstrated a rapid increase of nitric oxide within 60 minutes of injury ${ }^{17}$. Further increases in nitric oxide were seen in the first 72 hours. In central nervous system inflammation, monocytes and macrophages are the chief supply of cells releasing nitric oxide. In spinal cord injury, nitric oxide synthase, a required enzyme in nitric oxide production, is seen in macrophages, neurons, astrocytes, and oligodendrocytes. ${ }^{22}$ The oxidative properties of peroxynitrite (ONOO-), a nitric oxide-like compound formed readily in vitro from NO may accelerate local cell destruction. ${ }^{1-3}$ Peroxynitrite can damage tissue in various ways, all from radical formation and tissue destruction. Studies of pretreatment of nitric oxide synthase inhibitors, such as nitro-L-arginine (L-NNA) in the rat have been shown to limit the effects of spinal cord injury through comparisons of histological cord sections when compared to controls. ${ }^{27}$

The duration of effect of nitrous oxide is another consideration. An inhalational anesthetic, nitrous oxide is highly lipid soluble, traversing the blood brain barrier easily with a brief duration of onset and is cleared from the body by still unknown mechanisms in a matter of hours. Diffusion into lipid soluble tissues and then further breakdown into oxidative byproducts is the most likely candidate for clearance.

The use of steroids in spinal cord injury is highly controversial. ${ }^{23,32}$ Given the concern for an additional pathology contributing to the dramatic motor and sensory deficits, solumedrol was given in hope of reducing neurologic injury without a clear etiology. Steroids were not given for concerns of injury secondary to trauma, and the administration was not in accordance with the NASCIS guidelines. The mechanism for the mitigation of symptoms in spinal cord injury by steroids is still not completely understood. One credible theory is that steroids limit lipid peroxidation in secondary injury. Also, steroids are thought to have a decreased migration of leukocytes to damaged tissue, leading to a lower population of cells containing nitric oxide synthase, further limiting cell destruction. ${ }^{5}$ Ultimately, given the short half-life of nitrous oxide, one would expect the symptoms to have a short half-life.

\section{Conclusions}

We present a case of nitrous oxide myelopathy referred to our spinal cord injury center. History and radiographic presentation are key to establishing a diagnosis.

References

1. Bao F, DeWitt DS, Prough DS, Liu D: Peroxynitrite generated in the rat spinal cord induces oxidation and nitration of proteins: reduction by $\mathrm{Mn}$ (III) tetrakis (4-benzoic acid) porphyrin. J Neurosci Res 71:220-227, 2003

2. Bao F, Liu D: Peroxynitrite generated in the rat spinal cord induces apoptotic cell death and activates caspase-3. Neuroscience 116:59-70, 2003

3. Bao F, Liu D: Peroxynitrite generated in the rat spinal cord induces neuron death and neurological deficits. Neuroscience 115:839-849, 2002

4. Butzkueven $\mathrm{H}$, King JO: Nitrous oxide myelopathy in an abuser of whipped cream bulbs. J Clin Neurosci 7:73-75, 2000 
5. Cronstein BN, Kimmel SC, Levin RI, Martiniuk F, Weissmann G: A mechanism for the antiinflammatory effects of corticosteroids: the glucocorticoid receptor regulates leukocyte adhesion to endothelial cells and expression of endothelial-leukocyte adhesion molecule 1 and intercellular adhesion molecule 1. Proc Natl Acad Sci U S A 89:9991-9995, 1992

6. Diamond AL, Diamond R, Freedman SM, Thomas FP: "Whippets"-induced cobalamin deficiency manifesting as cervical myelopathy. J Neuroimaging 14:277-280, 2004

7. Eichhorn M, Watson M, Wurst F: [Polyneuropathy and myelopathy in N2O abuse within the scope of multiple drug abuse]. Psychiatr Prax 28:204-205, 2001

8. Gutmann L, Farrell B, Crosby TW, Johnsen D: Nitrous oxide-induced myelopathy-neuropathy: potential for chronic misuse by dentists. J Am Dent Assoc 98:58-59, 1979

9. Hathout L, El-Saden S: Nitrous oxide-induced B deficiency myelopathy: Perspectives on the clinical biochemistry of vitamin B. J Neurol Sci 301:1-8

10. Heyer EJ, Simpson DM, Bodis-Wollner I, Diamond SP: Nitrous oxide: clinical and electrophysiologic investigation of neurologic complications. Neurology 36:1618-1622, 1986

11. Kapustin SM, Raevskii VP: [Anesthesia in Operations on the Spinal Cord and Spine]. Vopr Neirokhir 27:20-24, 1963

12. Krajewski W, Kucharska M, Pilacik B, Fobker M, Stetkiewicz J, Nofer JR, et al: Impaired vitamin B12 metabolic status in healthcare workers occupationally exposed to nitrous oxide. Br J Anaesth 99:812-818, 2007

13. Lacassie HJ, Nazar C, Yonish B, Sandoval P, Muir HA, Mellado P: Reversible nitrous oxide myelopathy and a polymorphism in the gene encoding 5,10-methylenetetrahydrofolate reductase. Br J Anaesth 96:222-225, 2006

14. Layzer R: Neuromuscular Manifestations of Systemic Disease. Philadelphia: Davis, 1985

15. Layzer RB: Myeloneuropathy after prolonged exposure to nitrous oxide. Lancet 2:1227-1230, 1978

16. Layzer RB, Fishman RA, Schafer JA: Neuropathy following abuse of nitrous oxide. Neurology 28:504-506, 1978

17. Liu D, Ling X, Wen J, Liu J: The role of reactive nitrogen species in secondary spinal cord injury: formation of nitric oxide, peroxynitrite, and nitrated protein. J Neurochem 75:2144-2154, 2000

18. Lunsford JM, Wynn MH, Kwan WH: Nitrous oxide-induced myeloneuropathy. J Foot Surg 22:222-225, 1983

19. Marie RM, Le Biez E, Busson P, Schaeffer S, Boiteau L, Dupuy B, et al: Nitrous oxide anesthesiaassociated myelopathy. Arch Neurol 57:380-382, 2000

20. McLoughlin JL, Cantrill RC: Nitrous oxide induced vitamin B12 deficiency: measurement of methylation reactions in the fruit bat (Rousettus aegyptiacus). Int J Biochem 18:199-202, 1986

21. Meyers LE, Judge BS: Myeloneuropathy in a dentist. Clin Toxicol (Phila) 46:1095-1096, 2008

22. Murphy S, Simmons ML, Agullo L, Garcia A, Feinstein DL, Galea E, et al: Synthesis of nitric oxide in CNS glial cells. Trends Neurosci 16:323-328, 1993

23. Nesathurai S: Steroids and spinal cord injury: revisiting the NASCIS 2 and NASCIS 3 trials. J Trauma 45:1088-1093, 1998

24. Ng J, O'Grady G, Pettit T, Frith R: Nitrous oxide use in first-year students at Auckland University. Lancet 361:1349-1350, 2003

25. Pema PJ, Horak HA, Wyatt RH: Myelopathy caused by nitrous oxide toxicity. AJNR Am J Neuroradiol 19:894-896, 1998

26. Randt CT, Collins WF: Effect of anesthetic agents on spinal cord of cat. Am J Physiol 196:340342, 1959 
27. Sharma HS, Badgaiyan RD, Alm P, Mohanty S, Wiklund L: Neuroprotective effects of nitric oxide synthase inhibitors in spinal cord injury-induced pathophysiology and motor functions: an experimental study in the rat. Ann N Y Acad Sci 1053:422-434, 2005

28. Singer MA, Lazaridis C, Nations SP, Wolfe GI: Reversible nitrous oxide-induced myeloneuropathy with pernicious anemia: case report and literature review. Muscle Nerve 37:125-129, 2008

29. Smith WD: Pharmacology of nitrous oxide. Int Anesthesiol Clin 9:91-123, 1971

30. Somyreddy K, Kothari M: Nitrous oxide induced sub-acute combined degeneration of spinal cord: a case report. Electromyogr Clin Neurophysiol 48:225-228, 2008

31. Waters MF, Kang GA, Mazziotta JC, DeGiorgio CM: Nitrous oxide inhalation as a cause of cervical myelopathy. Acta Neurol Scand 112:270-272, 2005

32. Young W: NASCIS. National Acute Spinal Cord Injury Study. J Neurotrauma 7:113-114, 1990

\section{Figures}

Figure 1

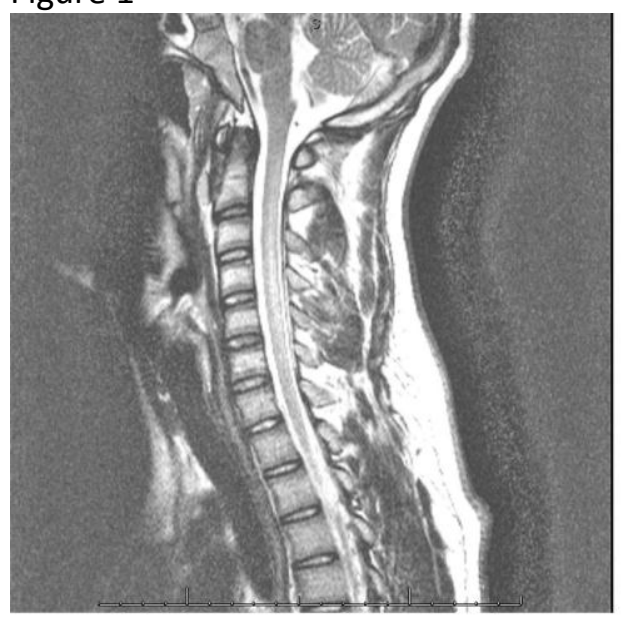

Figure 2 


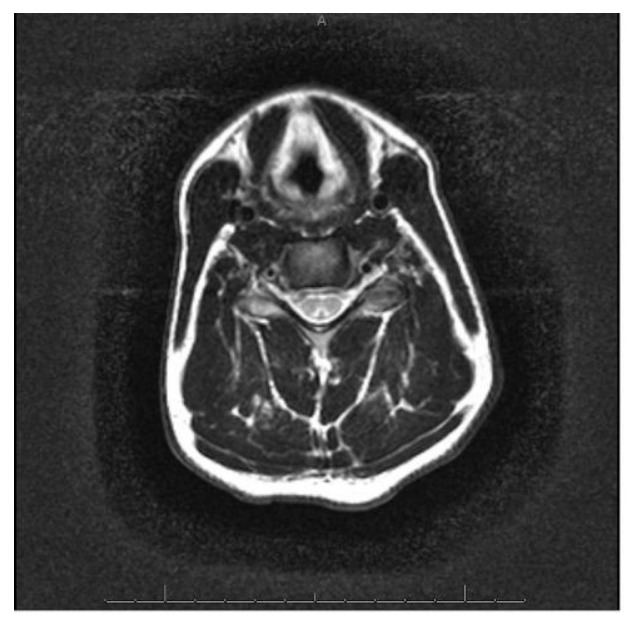

